\title{
Obesity inducing acute respiratory distress syndrome: we should choose the right population!
}

\section{Patrick M. Honore*, Leonel Barreto Gutierrez, Sebastien Redant, Keitiane Kaefer, Andrea Gallerani and David De Bels}

We read with interest the article of Palakshappa et al. which demonstrate that low levels of adiponectin were not associated with an increased risk of acute respiratory distress syndrome (ARDS) in patients with severe sepsis and septic shock [1] going against the hypothesis that low levels of adiponectin are the mechanism explaining the association of obesity with ARDS. It is unclear whether circulating adiponectin is involved in the pathogenesis of ARDS or simply represents an epiphenomenon. According to Rubenfeld et al., the most common risk factor from either a pulmonary or non-pulmonary source that accounts for $79 \%$ of ARDS cases is sepsis [2] and sepsis represents $80 \%$ of the risk factors for ARDS, and knowing that sepsis was present in $100 \%$ of the patients in this study [1], it is highly probable that sepsis is blunting the potential effects of obesity as a mechanism triggering ARDS in obese patients. Other risk factors include aspiration, lung contusion/trauma, acute pancreatitis, blood product transfusion, burn injury/smoke inhalation, cardiopulmonary bypass, and indeed obesity [2]. In addition, if we look carefully to the baseline characteristics of both populations with and without ARDS, some differences are intriguing. Regarding the incidence of chronic liver disease, we have $4 \%$ in the non-ARDS group vs $19 \%$ in the ARDS group $(P<0.009)$. It stands to reason that sicker patients have more risks of developing multiple organ failure including ARDS [3]. Also when looking at the Acute Physiology and Chronic Health Evaluation (APACHE) III score, with a more severe APACHE III being at risk of ARDS, it was 90 for non-ARDS vs 98 for ARDS $(P<0.003)$ [3]. Regarding the pulmonary source of sepsis, it was respectively $28 \%$ for non-ARDS versus $52 \%$ for ARDS $(P<0.02)$. Once again, a pulmonary source of sepsis can be more easily treated by antibiotics, whereas an extra-pulmonary source of

\footnotetext{
* Correspondence: Patrick.Honore@CHU-Brugmann.be

ICU Department, Centre Hospitalier Universitaire Brugmann- Brugmann

University Hospital, Place Arthur Van Gehuchtenplein, 4, 1020 Brussels, Belgium
}

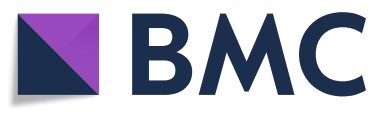

(C) The Author(s). 2019 Open Access This article is distributed under the terms of the Creative Commons Attribution 4.0 International License (http://creativecommons.org/licenses/by/4.0/), which permits unrestricted use, distribution, and

reproduction in any medium, provided you give appropriate credit to the original author(s) and the source, provide a link to the Creative Commons license, and indicate if changes were made. The Creative Commons Public Domain Dedication waiver (http://creativecommons.org/publicdomain/zero/1.0/) applies to the data made available in this article, unless otherwise stated. sepsis is more difficult to find and to control. Uncontrolled sepsis is a major risk factor for ARDS [4]. Adiponectin, an anti-inflammatory adipokine, is reduced in sepsis [5]. This low level of adipokine in sepsis may be a bias in this study as sepsis may further lower adipokine [5]. Altogether, confirming or not this relationship by choosing obese patients without sepsis would be an interesting study as sepsis could blunt the risk factor of obesity for ARDS. Other confounders should be eliminated for a further study as well.

\section{Abbreviations \\ ARDS: Acute respiratory distress syndrome; APACHE III: Acute Physiology and Chronic Health Evaluation III}

\section{Acknowledgements}

None.

\section{Authors' contributions}

$\mathrm{PMH}$ and DDB designed the paper. All authors participated in drafting and reviewing. All authors read and approved the final version of the manuscript.

\section{Funding}

Availability of data and materials

Not applicable.

Ethics approval and consent to participate Not applicable.

\section{Consent for publication}

Not applicable.

\section{Competing interests}

The authors declare that they have no competing interests.

Received: 14 September 2019 Accepted: 1 October 2019 Published online: 28 October 2019

\footnotetext{
References

1. Palakshappa JA, Anderson BJ, Reilly JP, Shashaty MG, Ueno R, Wu Q, et al. Low plasma levels of adiponectin do not explain acute respiratory distress syndrome risk: a prospective cohort study of patients with severe sepsis. Crit Care. 2016;20:71. https://doi.org/10.1186/s13054-016-1244-2.

2. Rubenfeld GD, Caldwell E, Peabody E, Weaver J, Martin DP, Neff M, et al. Incidence and outcomes of acute lung injury. N Engl J Med. 2005;353(16):
} 
3. Öz E, Saltürk C, Karakurt Z, Yazıııoğlu Moçin Ö, Adıgüzel N, Güngör G, et al. Risk factors for multiorgan failure and mortality in severe sepsis patients who need intensive care unit follow-up. Tuberk Toraks. 2015;63(3):147-57.

4. Montgomery AB, Stager MA, Carrico CJ, Hudson LD. Causes of mortality in patients with the adult respiratory distress syndrome. Am Rev Respir Dis. 1985;132(3):485-9.

5. Welters ID, Bing C, Ding C, Leuwer M, Hall AM. Circulating anti-inflammatory adipokines high molecular weight adiponectin and zinc-a2-glycoprotein (ZAG) are inhibited in early sepsis, but increase with clinical recovery: a pilot study. BMC Anesthesiol. 2014;14:124. https://doi.org/10.1186/1471-2253-14-124 eCollection 2014

\section{Publisher's Note}

Springer Nature remains neutral with regard to jurisdictional claims in published maps and institutional affiliations.

Ready to submit your research? Choose BMC and benefit from:

- fast, convenient online submission

- thorough peer review by experienced researchers in your field

- rapid publication on acceptance

- support for research data, including large and complex data types

- gold Open Access which fosters wider collaboration and increased citations

- maximum visibility for your research: over $100 \mathrm{M}$ website views per year

At BMC, research is always in progress.

Learn more biomedcentral.com/submissions 